\title{
Türkiye'de Gıda Perakendeciliği Sektöründe Finansal Analiz ve Bir Uygulama
}

\author{
Yakup ÜLKER ${ }^{1}$ ve Öznur ARSLAN ${ }^{2}$
}

Öz

Çalıșma, BIST-Perakende Ticaret Sektöründe işlem gören 3 market zincirinin (BIM, MIGGROS, CARREFOURSA) finansal analiz türlerinden oran analizi yöntemiyle finansal performanslarını tespit etmeyi ve market zincirlerinin dönemler bazında finansal performanslarını karşılaştırmayı amaçlamıştır. Bu bağlamda araştırmada, market zincirlerinin kamuoyuna açıladığı ve bağımsız denetimden geçmiş 2015-2018 yıllarına ait olan IMKB'de yayımlanmış finansal tabloları kullanılmıştır. Analizi yürütmek için, seçilen firmaların mali tablolarına; likidite, faaliyet, mali yapı ve karlılık oranları uygulanmıştır. Çalışmanın sonucunda, şirketler karşılaştırıldığında nispi olarak likidite oranı yükseklik düzeyi sıralaması MİGROS, BİM MAĞAZALARI ve CARREFOURSA olarak gerçekleşirken, MİGROS firmasının alacak devir hızı diğer şirketlere kıyasla daha yüksektir. BİM Mağazalarının stok ve aktif devir hızı diğer firmalara göre daha yüksektir ve stoklara daha az fon bağlamıștır. Kısa vadeli borçların vade yapısı bakımından durumu en iyi olan firmanın MİGROS firması olduğu görülmektedir. Kısa vadeli borçlarını karşılama bakımından en zayıf firmanın CARREFOURSA firması olduğu söylenebilir. Faaliyet karlılı̆ı oranı bakımından durumu en iyi olan firma BİM market zinciri olduğu görülmektedir. Net kar oranı bakımından durumu en olumsuz olan firmalar CARREFOURSA ve MIGROS șirketleridir. MIGROS firması (2017 ylı hariç) ile CARREFOURSA firmasının 2015-18 yılları arasında zarar etmiș olması öz kaynak karlılığını olumsuz yönde etkilemiştir. Aktif karlılık oranı en iyi olan firma BİM Marketler zinciridir. Aktif karlılık oranı bakımından durumu en zayıf olan firmanın CARREFOURSA olduğu görülmektedir. Bu değerlendirmeler ışığında, ülke için vazgeçilmez olan gıda perakendecilik sektöründeki firmaların bazıları verimli ve yatırıma elverişli bir tablo çizerken bazıları ise yatırım açısından etkin bir performans sergileyememişlerdir.

Anabtar Kelimeler: Finansal oran, G1da perakende sektörü, Finansal performans, Analiz, Firma değeri

\section{Financial Analysis and an Implementation on Food Retailing Industry in Turkey}

\section{Abstract}

The present study aims to determine the financial performances of 3 grocery store chains (BIM, MİGROS, CARREFOURSA), which are traded in BIST-Retail Sector, by using ratio analysis that is one of the financial analysis methods and to compare the financial performances of chains by seasons. From this aspect, the chains' 2015-2018 financial statements, which have been publicized by the chains and published by IMKB, were used in the present study. In performing the analyses, the liquidity, operation, financial structure, and profitability ratios were applied to the financial statements of selected companies. As a result of the study, the companies were compared and the descending sort of companies is as follows: MIGROS, BIM, and CARREFOURSA. On the other hand, the accounts receivable turnover of MIGROS was found to be higher than the others. The inventory turnover and asset turnover rates of BİM Stores were higher than other and they invented less in stocks. MIGROS was found to be the best from the aspect of the maturity structure of short-term debts. CARREFOURSA was found to be the weakest company in terms of short-term debt coverage ratio. BIM was found to be in the best conditions in terms of operating profitability. The most negative companies in terms of net profit ratio were CARREFOURSA and MIGROS. MIGROS (except for the year 2017) and CARREFOURSA made losses between 2015 and 2018 and it negatively affected their return on equity. The company with the highest return on assets was found to be BIM Grocery Store Chain. The company having the lowest return on assets was found to be CARREFOURSA. The food retailing industry is a necessity for the country. As a result of analyses, it was determined that, although the positive advancements were achieved in the sector and it is suitable for investment for several companies, some companies couldn't perform efficiently enough from the aspect of investment.

Key Words: Financial ratio, Food retailing industry, Financial performance, Analysis, Firm value

\section{Atıf İçin / Please Cite As:}

Ülker, Y. ve Arslan, Ö. (2020). Türkiye'de g1da perakendeciliği sektöründe finansal analiz ve bir uygulama. Manas Sosyal Araşttrmalar Dergisi, 9(4), 2531-2546.

Geliş Tarihi / Received Date: 19.01.2020

Kabul Tarihi / Accepted Date: 02.05.2020

\footnotetext{
${ }^{1}$ Dr. Öğr. Üyesi - Sivas Cumhuriyet Üniversitesi, İ.İB.F. - yulker@hotmail.com ORCID: 0000-0002-3070-0521

2 Dr. Öğr. Üyesi - Sivas Cumhuriyet Üniversitesi, Cumhuriyet Meslek Yüksekokulu - oznurkul@cumhuriyet.edu.tr ORCID: 0000-0001-5973-9107
} 


\section{Giriş}

Günümüzde rekabetin yoğun yaşandığı alanlardan birisi olan gıda perakende sektörü; perakende pazar payının en önemli payına sahiptir. Geçmiş birkaç yıldan bu yana mahallelerde yer alan küçük gıda işletmeleri, yerlerini orta ve büyük ölçekli mağazalara bırakmıştır. Bu mağazaların giremediği mahalleler artık bir pazar alanı olarak görülmekte ve rekabetin çetin olduğu yerler arasında sayılmaktadır. Bu sebeple gıda perakende işletmeleri, ellerindeki bütün kaynakları, yeni mağaza zinciri açma konusunda kullanmaktadırlar. Bu perakende işletmeleri, bakkal olarak tanımladığımız en küçük gıda marketleriyle, hipermarket olarak tanımladığımız en büyük gida marketleri arasında yer alarak bütün kesimlere hitap etmektedir. İnsanların her türlü ihtiyaçlarını karşılayan bu mağazalar ülkemizde alışveriş için tercih edilen en gözde mekânlardan olmuştur. Bunun yanında bu sektörde elde edilen ylllk cironun kayda değer bir kısmını bu mağazalar almaktadır. Kısacası bu mağazalar gıda perakende sektörünün lokomotifidir diyebiliriz (Karahan, 2014, s. 1).

Lokomotif olarak ifade ettiğimiz bu işletmelerin bilgilerinden faydalanan birçok çıkar grubu vardır. Devlet, çalışanlar, tedarikçiler, müşteriler ve kredi kurumları bunlardan bazılarıdır. Yatırımcıların yatırım yapabilmesi, kreditörlerin sağlıklı bir kredi politikası belirlemesinde işletmenin sektörel durumu, rekabet ortamı, diğer kişi ve kuruluşlarla ilişkisi gibi durumların yanı sıra finansal bilgilerin incelenip değerlendirilmesi de önem arz etmektedir. Bu sebeplerle işletmelerin mali durumunu ortaya koyan finansal durum analizlerinin yapılması işletme çıkar gruplarının sağlıklı karar alması için zorunlu bir hal almıştır (Bodur, 2006, s. 51).

Bu bağlamda çalışmanın amacı, BIST-Perakende Ticaret Sektörü’nde işlem gören 3 market zincirinin (BIM, MIGROS, CARREFOURSA) finansal analiz türlerinden oran analizi yöntemiyle finansal performanslarını tespit etmektir. Çalışmada Türkiye'de perakendecilik sektörünün genel yapısı hakkında bazı bilgiler verildikten sonra söz konusu işletmelerin oran analizi yöntemiyle finansal durumları hakkında performans değerlendirmeleri yapılmıştır.

\section{Türkiye’de Perakendecilik Sektörünün Genel Yapısı}

Perakendecilik, "tüketicilere kişisel veya ailesel kullanımlarını sağlamak amacıyla, doğru ürün veya hizmetin, doğru fiyatla ve doğru zamanda tüketiciye sunulması yoluyla değer katan bir dizi işletme faaliyeti olarak" tanımlanmaktadır (Levy ve Weitz, 2004, s. 6).

Türkiye'de perakende sektörünün cirosu 2019 sonu itibarıyla 170 milyar dolar civarındadır (https://www.ekonomist.com.tr). Bu cironun yaklaş1k olarak \% 67'si geleneksel, \%33’ü ise organize perakendeden oluşmaktadır (Özden ve Ersan, 2019: s. 8).Sektör gıda perakendeciliği ve gıda dış1 perakendecilik olarak ayrılmaktır. Aynı zamanda temel ihtiyaçlar ve temel olmayan ihtiyaçlar şeklinde de sınıflandırılabilmektedir. Temel ihtiyaçlar, tarım odaklı kırsal kesimlerde toplam perakende harcamalarının büyük payını oluşturmaktadır.

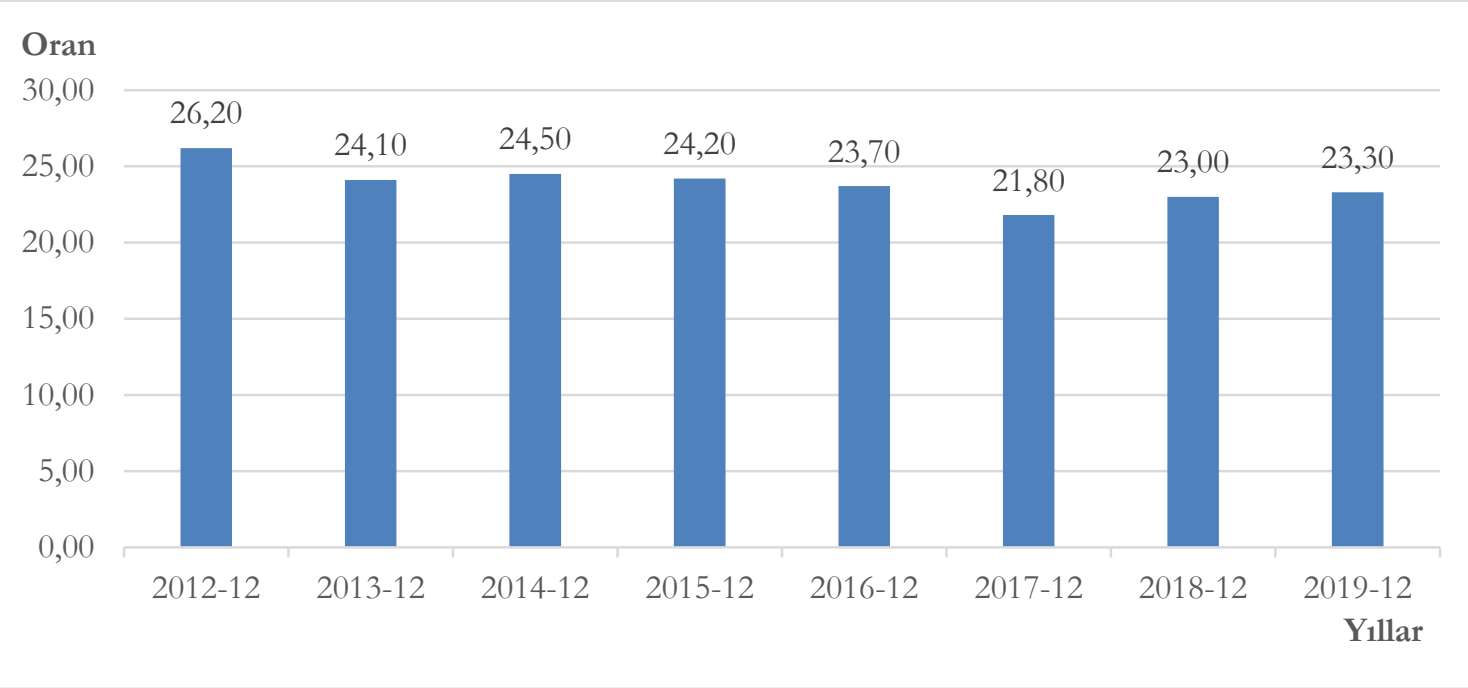

Şekil 1. Gıda ve Alkolsür İgeceklerin Tüketici Harcama Sepetindeki Payn (Kaynak: TÜIK) 
Önümüzdeki dönemde gıda perakendecileri için genel görünüm, kentleşmenin artması ve genç nüfusun demografik olarak daha fazla hazır gida tüketimi ve market harcamasıyla gida perakende satışlarına olan talebin artması şeklinde olacaktır. Nitekim aşağıdaki gıda, içecek ve tütün perakende satış hacim endeksi de bu bulgularımızı destekliyor. Endeks 2010 yllından beri kesintisiz şekilde artmakta olup son sekiz yılda ortalama $\% 4$ seviyesinde büyümüştür. Türkiye gıda perakende sektörünün hem istihdama hem de çarpan etkisi sayesinde büyüme ve kamu bütçesine katkısı bulunmaktadır (Özden ve Ersan, 2019, s. 12).

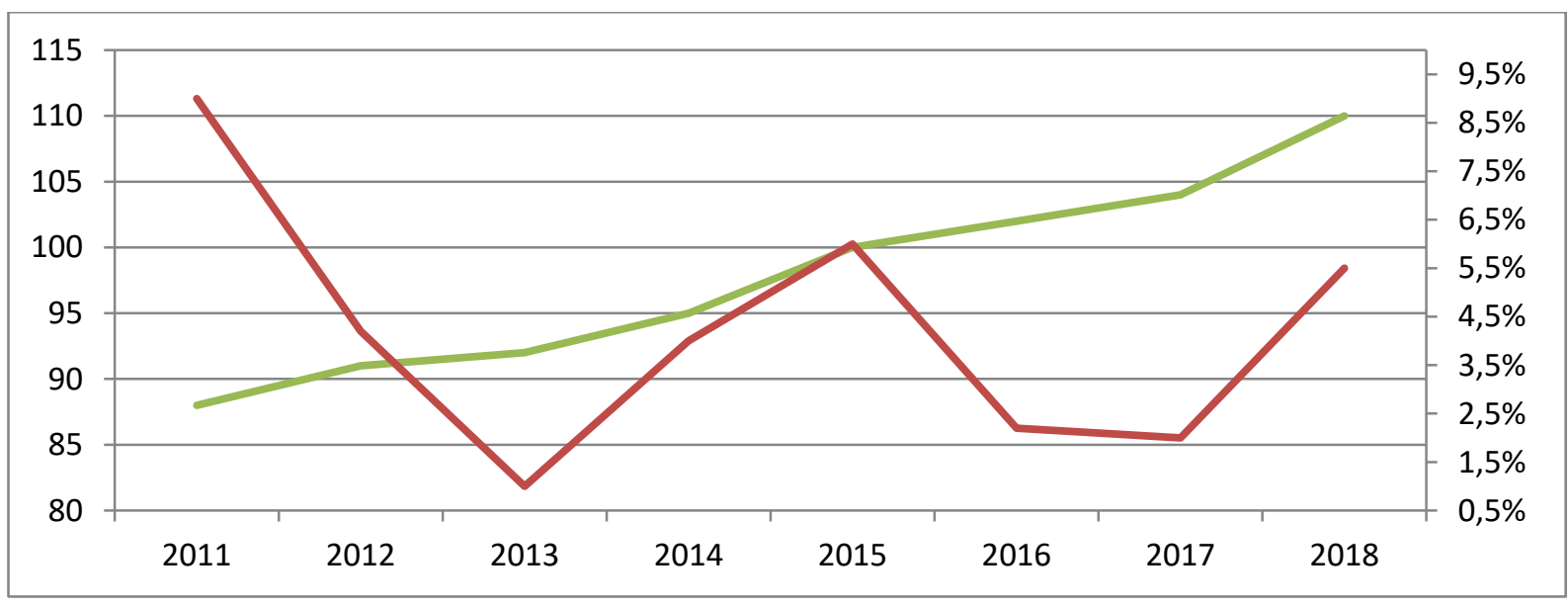

Şekil 2. Perakende Satış Hacim Endeksi Gıda, İcecek ve Tütün (Yıl Ortalaması) (Kaynak: TÜIK)

Oluşturduğu toplam istihdam bakımından tüm sektörler içerisinde ikinci sırayı alan perakende sektöründe çalışan devir oranları şirket verimliliğini en çok etkileyen faktörlerin başını çekiyor. TÜIKK tarafindan açılanan resmi istatistikler, 2015 yllında perakende sektörü çalışan sayısının 1 milyon 826 bin kişi olduğunu gösteriyor. 2016 ve 2017 Eylül dönemine kadar olan perakende sektörü SGK değişim oranlarından yola çıkarak, 2016 yllında sektör istihdamı 1 milyon 810 bin kişi düzeyinde gerçekleşti. Perakendede istihdam edilen kişi sayısı 2017 yılı Eylül sonunda ise tahminen 1 milyon 925 bin kişiye ulaştı (KPMG, 2018, s. 10).

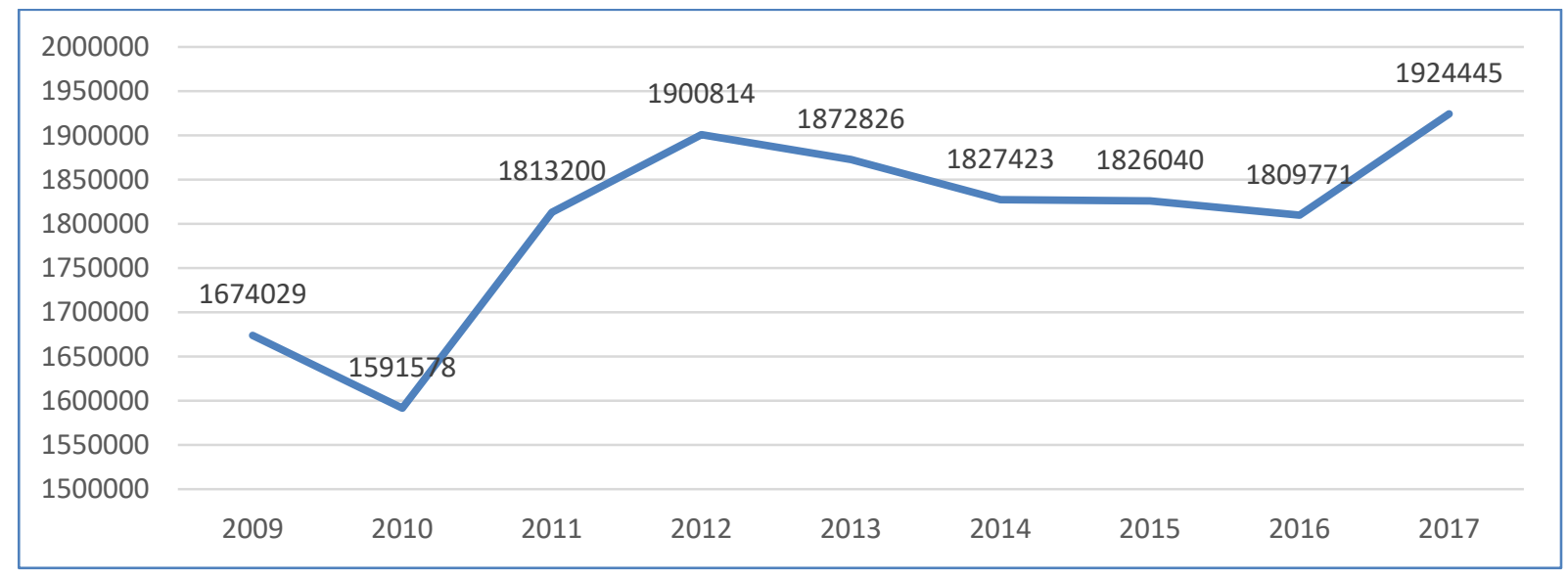

Şekil 3. Perakende Sektörü Callşan Saynlarn (2009-2017) (Kaynak: KPMG, 2018, s. 10)

Yıllara göre değerlendirme yapıldığında sektör, istihdam oranlarını yukarlara taşıyabilmektedir. Türkiye'de yer alan işsizlik oranlarılla genç nüfus dinamiklerinin sektörün istihdam ihtiyacını diğer sektörlere nispeten daha iyi karşıladığı gözlenmektedir.

Perakende ciro endeksi ise cari fiyatlar ile perakende satışlarını ölçmekte olup 2017 yllından itibaren hızlanmıştır. Türkiye perakende pazarı yerel ve uluslararası zincir mağazaları ile büyümekte olup, son zamanlarda satın alma ve birleşmeler ile birlikte daha da büyümüştür. 


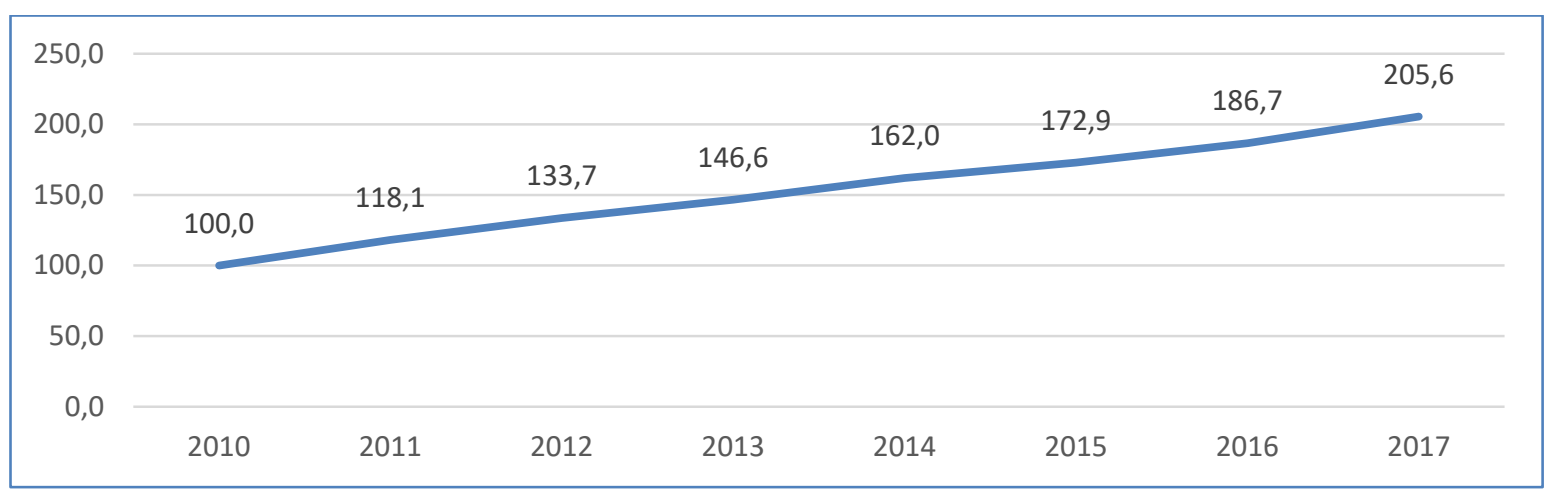

Şekil 4. Perakende Ciro Endeksi - Yullhk Değğsim 2010-2017 (Kaynak: KPMG, 2018, s. 12)

2017’ye, bir önceki yılla karşılaştırıldığında yüksek bir ciro ile giren perakende sektörü, 2016'nın aynı dönemiyle karşılaştırıldığında yüzde 11 ciro büyümesi yakaladığı görülmektedir.

\section{Mali Tablolar Analizi ve Türleri}

Bilanço, gelir tablosu, fon akım tablosu ve öz kaynak değişim tablosu gibi mali tablolar işletmelerin finansal durumları hakkında önemli bilgi sağlar. Mali analiz ise, "mali tablolar arasında yer alan çeşitli kalemler arasında karşılaştırmalar, yüzdeler ve oranlar yolu ile ilişkiler kurmak ve bu ilişkilerin ölçülmesi ve yorumlaması olarak" tanımlanır. Analizlerle işletmelerin nereye doğru gittiği, kalemler arasındaki ilişkilerin ve değişimlerin ne anlama geldiği gibi konular hakkında tahminlemelerde bulunulur (Çetiner, 2007, s. 7).

Bu bağlamda mali analizin temel amact; işletmenin geçmiş başarısını değerlendirerek güçlü ve zayıf yanlarını ortaya çıkarmak ve işletme ile ilgili taraflara, işletme ile ilgili verecekleri kararlarda finansal bilgi desteği sağlamak ve sonuçta atılacak adımların doğruluk derecesinin artırlmasına katkı sağlamak olduğu ifade edilebilir.

Mali analiz ile aşağıdaki konular hakkında bilgiler elde edilir (Arda ve Göğebakan, 2003, s. 61):

- İşletmelerin varlıklarının dağglımını ve verimli kullanılıp kullanılmadığını,

- İssletme kaynakların etkin kullanılıp, kullanılmadığı ve kaynaklardan faydalanma derecesini,

- İşletmelerin kısa ve uzun vadeli borçları ödeme güçlerini,

- İşletme karlılığının tespitini ve borsa performansının değerlendirilmesini,

- İşletme aktif karll11k düzeyi,

- Nakit, stok ve alacaklar gibi varlıkların yönetiminin etkinliğini.

Mali tablolar analizi genel olarak Karşılaştırmalı Mali Tablolar Analizi, Dikey Yüzde Analizi, Yatay Yüzde Analizi (Trend Analizi) ve Oran Analizi yöntemleri kullanılarak yapılır.

Oran analizi finansal tablolarda yer alan herhangi iki kalem arasındaki nispi ilişkiyi göstermektedir. Bu bakımdan oran analizi finansal tablolarda yer alan finansal kalemlerin kullanılması ile işletme hakkında detaylı bilgi edinilmesine imkân sağlamaktadır (Yılmaz ve Aslan, 2018, s. 40). İşletmenin; belli bir dönemi veya bir birini takip eden dönemlerine ait borç ödeme kabiliyeti, varlıklarını kullanma verimliliği, mali yapısındaki risklilik derecesi ve karlılı̆̆1 gibi konular üzerinde güçlü ve zayıf yönler detaylı olarak incelendiği için oran analizi hem statik ve hem de dinamik analize uygun bir tekniktir.

Finansal analizde kullanılan oranlar amaç ve fonksiyonlara göre dört guruba ayrılmaktadır; Kısa vadeli borç ödeme gücünü gösteren likidite oranları; varlıkların nereden finanse edildiğini gösteren mali yap1 oranları; varlıkların devir süresini gösteren faaliyet oranları ve işletmenin çeşitli açılardan kârlılığını gösteren kârlılık oranları olmak üzere dört temel nokta üzerinden gerçekleştirilen oran analizi, hem işletmenin sadece bir dönemine ait finansal durumunu ortaya koymakta ve hem de bir birini takip eden dönemler ile kıyaslanarak daha anlamlı bir yorum yapılmasına imkân sağlamaktadır. 


\section{Literatür Taraması}

İşletmelerin durumunu geçmiş dönemler, sektör ortalamaları ve standart oranlarla kiyaslamaya olanak tanıyan ve bu sayede işletmelerin hayatta kalabilmesini sağlayan mali analiz teknikleri kullanılarak yapılan akademik çalışmalardan bazıları aşağıda sıralanmıştır.

Steed vd (2003), otel işletmelerinin uygulamış oldukları tam pansiyon ve yarı pansiyon (oda-kahvaltı) programındaki odaların toplam kâra katkılarını finansal oranlar yöntemi kullanarak hesaplamışlardır. Schmidgall ve Defranco (2004), otel ve yiyecek işletmelerinin finansal başarılarını oran analizleri yöntemi kullanarak incelemişlerdir. Buraimo vd. (2006), İngiliz futbol kulüplerinin finansal performanslarını oran yöntemi kullanarak analiz etmişlerdir. Hulusi Yağlıca (2006), çalışmada, İstanbul Sanayi Odasının (ISO) açıkladığı Türkiye'nin 500 Büyük Sanayi Kuruluşlarının, 1979-2003 yılları arasındaki mali raporları derlenerek on beş tane finansal oran hesaplanmış ve trend analizi gerçekleştirilmiştir. Dumanoğlu ve Ergül (2010), İMKB'de işlem gören on bir teknoloji mali tablolarını kullanarak oran analizi yapmış ve bu oranlar üzerinden TOPSIS yöntemi aracıllğıyla şirketlerin mali performansını ölçmüştür. Dimitropoulos (2010), çalısmalarında Yunan futbol kulüplerinin 1994-2004 yılları arasındaki finansal performanslarını oran analizi ile incelemiştir. Akın ve Ece (2013), İMKB'de işlem gören sigorta şirketlerini ele aldığ1 çalışmada bu şirketlerin 2006-2010 dönemine ait finansal performanslarını ölçmek amacıyla oran analizi ve karşılaştırmalı tablolar analizi yöntemlerini kullanmışlardır. Karadeniz vd. (2014), Borsa İstanbul'da (BİST) işlem gören dört spor şirketinin finansal performansını oran analizi yöntemiyle belirleyip bu şirketlerin iflas risklerini tespit etmeyi amaçlamışlardır. Karadeniz vd. (2015), karayollarında yolcu taşımacılı̆̆ yapan işletmelere ait TCMB tarafindan yayımlanan finansal oranları kullanarak oran analizi yöntemine göre söz konusu sektörün finansal durumunu yorumlamışlardır. Şen vd. (2015), örnek otel işletmesinin mali tablolarını finansal analiz yöntemlerini kullanarak analiz etmişler ve finansal analizin otel işletmelerinin hedeflerine ulaşmasında ve başarısında önemini irdelemişlerdir. Gümüş ve Bolel (2017), rasyo analizleriyle İstanbul'da faaliyet gösteren hava yolu şirketlerinin 2010-2015 mali tabloların incelemişlerdir. Çalış vd. (2018), çalışmalarında BIST’te faaliyet gösteren konaklama işletmelerini oran analizi ve diğer analizlerle incelemişlerdir. 2013-2017 yıllarını inceleyen araştırmacılar, 2016 yllında Rusya ile yaşanan "uçak krizi”nin söz konusu turizm işletmelerinin finansal performansı üzerinde etkili olup olmadığını değerlendirmişlerdir. Önal vd. (2018), çalışmalarında hava taşımacılı̆̆ı işletmelerini Türkiye ve Avrupa olmak üzere oran analizi yöntemiyle karşılaştırmalı olarak incelemişlerdir. Guo ve Wang (2019), bir İngiliz perakende firmasının finansal rasyolarını yine iki büyük perakende firması olan Tesco ve Morrison'un finansal rasyolarıly karşılaştırmalı olarak incelemişlerdir. Yenisu(2019) çalışmasında, Adese Alışveriş Merkezleri Ticaret A.Ş.'nin 2014-2016 arası verilerine oran analizi yöntemi uygulamışır.

Görüldüğü gibi oran analizi yöntemi bütün sektörlerdeki işletmelerin finansal performans düzeylerini ölçmede kullanılabilen bir tekniktir.

\section{Araştırma Metodolojisi}

\section{Araştırmanın Amacı}

Bu çalışmanın amacı, BIST-Perakende Ticaret Sektöründe işlem gören 3 market zincirinin finansal analiz yöntemlerinden oran analiziyle finansal performanslarını tespit etmektir. Bu amaca ek olarak, market zincirlerinin dönemler bazında finansal performanslarının karşılaştırması da yapılmışıı.

\section{Veri Toplama Yöntemi}

BIST-Perakende ve Ticaret Sektöründe 12 perakende firması bulunmaktadır. Bu firmalardan; Bİ, MIGROS ve CARREFOURSA firmaları de bu sektörde market zinciri olarak faaliyet göstermektedir. Çalışmada market zincirlerinin kamuoyuna açıkladığı ve bağımsız denetimden geçmiş 2015-2018 yıllarına ait olan İMKB'de yayımlanmış finansal tabloları kullanılmışır. BIST’te Gıda Sektöründe işlem gören 12 perakende firması içerisinde ilgili dönemler için verilerini düzenli olarak elde edilen 3 firmanın mali tabloları analizde kullanılmıştır. Gıda marketleri piyasasında; MİGROS ve CARREFOURSA marketlerinden genellikle orta ve yüksek gelir düzeyine sahip müşterilerin alış veriş yaptığ1 ve BİM market zincirinden ise orta ve alt gelir düzeyine sahip müşterilerin alış veriş yaptığ1 ve ürün fiyatlarının BİM marketlerinde MIGROS ve CARREFOURSA marketlerine göre daha uygun fiyatla satıldığ1 algısı vardır. $\mathrm{Bu}$ alg1 firma verimliliği ve karlılığını etkilemektedir. Bu hususlar da dikkate alınarak analiz yapılacaktır. 
ÜLKER ve ARSLAN

Türkiye'de Gıda Perakendeciliği Sektöründe Finansal Analiz ve Bir Uygulama

Tablo 1. Türkiye Gıda Perakendecileri

\begin{tabular}{lc}
\hline Grup (Açllş̧ yılı) & Mağaza Sayıları \\
\hline MİGROS (1954) & 2131 \\
\hline BIM (1995) & 8152 \\
\hline CARREFOURSA (1993) & 640 \\
\hline
\end{tabular}

Kaynak: www.bim.com.tr; www.migroskurumsal.com.tr; www.carrefoursa.com.tr

\section{Araştırmanın Analiz Süreci}

Finansman yöneticileri oran analizlerini mali tablolarda yer alan verileri yorumlamak amaciyla kullanmaktadırlar. Finansal oranların hesaplanması her ne kadar kolay matematiksel işlemlerden oluşmuş olsa da, firmaların performanslarını etkin bir şekilde de ölçmek için dikkatli bir şekilde analize tabi tutulması gerekmektedir (Demir ve Tuncay, 2012, s. 378). Başarılı bir oran analizi için anlamsız oran kullanılmamalı, oranlar amaçlara uygun yorumlanmalı, mevsimlik ve konjonktürel hareketler dikkate alınmalı, firmaların geçmiş bilgilerinin yanında sektörün genel gidişi de dikkate alınmalı ve gelecekle ilgili hareket planlarına katkı sağlamak amaçlanmalıdır.

Gıda sektöründe finansal performanslarını incelemek üzere seçilmiş oranlar, BIST’te kayıtlı Perakende Ticaret Sektöründe işlem gören 3 market zincirinin mali tablo verileri üzerinde uygulanmıştır. Uygulama için seçilen oranlar Tablo 2'de listelenmiştir

Tablo 2. Calısmada Kullanılan Oranlar ve Formülleri

\begin{tabular}{|c|c|}
\hline \multicolumn{2}{|l|}{ Seçilmiş Oranlar } \\
\hline Oran Ad1 & Likidite Oranları \\
\hline Cari Oran & Dön Varlıklar/ K.V.Y.K \\
\hline Likidite Oran & (Dön. Var. - Stoklar)/ K.V.Y.K \\
\hline Nakit Oran & (Haz. Değ.+Men. Kiy.)/ K.V.Y.K \\
\hline Oran Adı & Faaliyet (Varlık Kullanım) Oranları \\
\hline Alacak Devir Hızı & Net Satışlar/ Ort. Ticari Alck. \\
\hline Aktif Devir Hizı & Net Satıslar/ Aktif Toplam \\
\hline Stok Devir Hiz1 & Satılan Malın Maliyeti/Ort. Stoklar \\
\hline Net Çalışma Sermayesi Devir Hızı & Net Satışlar/Çalışma Sermayesi \\
\hline Maddi Duran Varlık Devir Hızı & Net Satışlar/Maddi Duran Varlık (Net) \\
\hline Oran Adı & Mali Yapı Oranları \\
\hline Yabancı Kaynak Oranı & Top. Yab. Kayn./Pasif Toplam \\
\hline Öz Kaynak Oranı & Öz kaynaklar / Pasif Toplam \\
\hline Yabancı Kaynakların Öz kaynaklara Oranı & Top. Yab. Kayn./Öz kaynaklar \\
\hline Yabancı kaynak Vade Yap. Oranı & K.V.Y.K/Toplam Yab. Kaynak \\
\hline Kısa Vad. Yab. Kaynak Oranı & K.V.Y.K/Pasif Toplam \\
\hline Uzun Vad. Yab. Kaynak Oran1 & U.V.Y.K/ Pasif Toplam \\
\hline Duran Varlık / Öz kaynak & Duran Varlık / Öz kaynak \\
\hline Oran Ad1 & Karlılık Oranları \\
\hline Brüt Kar Oranı & Brüt Satış Karı / Net Satışlar \\
\hline Faaliyet Karı Oranı & Faaliyet Karı/ Net Satışlar \\
\hline Net Kar Oranı & Dönem Net Karı / Net Satışlar \\
\hline Öz Kaynak Karlılık Oranı & Dönem Net Karı /Öz Kaynaklar \\
\hline Aktif Karlılık Oranı & Dönem Karı/ Aktif Toplam \\
\hline
\end{tabular}




\section{Gıda Perakendeciliği Sektöründe Yer alan İşletmelerin Finansal Analizi}

\section{İşletmelerin Likidite Oranları Açısından İncelenmesi}

İşletmelerin kısa vadeli yabancı kaynaklarını zamanında ödeyip ödeyemeyeceğini ve işletmelerin net işletme sermayelerinin yeterli düzeyde olup olmadığının tespitinde bir ölçü olarak likidite oranları kullanılır. Kısa vadeli borçları ödemede kullanılan kaynaklar dönen varlıklar arasında yer alır.

Dönen varlıklar ile kısa vadeli yabancı kaynaklar arasındaki ilişkileri gösteren üç temel oran vardır (Çabuk ve Lazol, 2009, s. 208).

a. Cari Oran: Her sektörde farklı olmakla birlikte oranın 2 olması genellikle yeterli kabul edilir. Bu oran her 1 TL'lik borca karşılık 2 TL'lik dönen varlık bulundurulmasını ifade etse de sermaye piyasalarının yeterli düzeyde gelişmediği ülkelerde oranın 1,5 olması yeterli kabul edilir. Oranın yüksek olması kredi verenler için iyidir ama işletmede fonların etkin ve verimli kullanılmadığını da ifade eder. Her şeye rağmen bu oran 1'in altında olmamalıdır.

b. Likidite (Asit-Test) Oranı: Bu oran cari oranı tamamlar ve daha anlamlı hale getirir. Stokları dönen varlıklardan ayırdığı için daha keskin bir orandır. Ödeme gücünün belirlenmesinde stokların paraya çevrilmeme riskini ortadan kaldırır. Yine sektörel bazda değişmekle birlikte oranın 1 olması yeterli kabul edilir.

c. Nakit Oran: İşletmenin elindeki mevcut hazır değerler ile kısa vadeli borçların ne ölçüde karşılandığını gösterir. Diğer oranlara göre daha hassas olan bu oran da söktörel bazda farklı olmakla birlikte genellikle 0,20 olması yeterli kabul edilir.

Tablo 3. Likidite Oranlar

\begin{tabular}{|c|c|c|c|c|c|c|c|c|c|c|c|c|c|}
\hline \multirow{2}{*}{\multicolumn{2}{|c|}{ Seçilmiş Oranlar }} & \multicolumn{4}{|c|}{ BİM MAĞZALARI } & \multicolumn{4}{|c|}{ CARREFOURSA } & \multicolumn{4}{|c|}{ MİGROS } \\
\hline & & \multicolumn{12}{|c|}{ Yillar } \\
\hline Oran Ad1 & $\begin{array}{l}\text { Likidite } \\
\text { Oranları } \\
\end{array}$ & 2015 & 2016 & 2017 & 2018 & 2015 & 2016 & 2017 & 2018 & 2015 & 2016 & 2017 & 2018 \\
\hline Cari Oran & $\begin{array}{c}\text { Dön Var. / } \\
\text { K.V.Y.K } \\
\end{array}$ & 0,901 & 0,894 & 0,940 & 0,944 & 0,592 & 0,489 & 0,456 & 0,508 & 0,791 & 0,894 & 1,159 & 1,252 \\
\hline $\begin{array}{l}\text { Likidite } \\
\text { Oran }\end{array}$ & $\begin{array}{l}\text { (Dön. Var. - } \\
\text { Stoklar) / } \\
\text { K.V.Y.K }\end{array}$ & 0,494 & 0,517 & 0,560 & 0,535 & 0,221 & 0,226 & 0,238 & 0,242 & 0,371 & 0,456 & 0,573 & 0,622 \\
\hline $\begin{array}{l}\text { Nakit } \\
\text { Oran }\end{array}$ & $\begin{array}{l}\text { (Haz. Değ. + } \\
\text { Men. Kuy.) / } \\
\text { K.V.Y.K }\end{array}$ & 0,145 & 0,195 & 0,256 & 0,194 & 0,166 & 0,129 & 0,185 & 0,203 & 0,336 & 0,419 & 0,499 & 0,495 \\
\hline
\end{tabular}

Bu bağlamda Tablo 3 incelendiğinde; gerek incelenen yıllar ve gerekse şirketler açısından;

Cari oran düzeyleri genel standart olarak kabul edilen 2'nin veya 1,5'in altındadır. Genel standart yanında şirketlerin dâhil olduğu sektör ortalamasının da dikkate alınması gerekir. Son iki yıl açısından MIGROS şirketinde kısmi bir iyileşme gözlenmekle birlikte genel olarak cari oranın 1 'in altında kalması finans piyasalar açısından riskli olduğu şeklinde değerlendirebiliriæ: Bu hususlar dikkate alınarak incelenen şirketler karşılaştırıldığında nispi olarak cari oran yükseklik düzeyi sıralaması MIGROS, BIM MAĞAZALARI ve CARREFOURSA olarak gerçekleşmiştir. Ancak bu şirketlerin kısa vadeli borçlarmı karşslama açısından risk altında olduğu söylenebilir.

Likidite oranları cari oranın tamamlayıcısı niteliğindedir ve stoklardan gelebilecek ödeme riskini ortadan kaldırır. İncelenen yıllar ve şirketler incelendiğinde genel standart olarak kabul edilen 1 'in

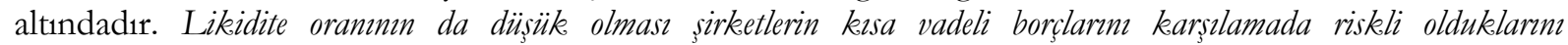
göstermektedir. Bununla birlikte incelenen market zincirleri karşılaştırıldığında nispi olarak likidite oranı yükseklik düzeyi sıralaması MİGROS, BİM MAĞAZALARI ve CARREFOURSA olarak gerçekleşmiştir.

Nakit oranları bakımından durumu en iyi olan market zinciri MIGGROS firmasıdır. Bu şirketin yıllar itibariyle nakit oranı 0,20'nin üzerindedir. Yaklaşık olarak genel standardın 2 katıdır. Ancak bu durum borç ödeme açısından iyi olmakla birlikte firmanın elinde gereğinden fazla nakit bulundurduğunu göstermektedir. Bu durumun firma karlılığ üzerinde olumsuz etki yapacağını belirtmek gerekir. BİM ve CARREFOURSA firmalarının nakit oranları genel standarda yakın olarak izlenmiştir.

Bu üs oran birlikte değerlendirildiğinde 3 firmann nakit oran düreyleri yeterli olsa bile kessa vadeli borclarmm ödeme konusunda riskli olduklar söylenebilir. Bununla birlikte daha kesin bir yargiya varabilmek için stokların ve alacakların devir hızları ve borçların ödeme süreleri şirketlerin likidite oranlarını etkiler. 


\section{İşletmelerin Faaliyet (Varlık Kullanım) Oranları Açısından İncelenmesi}

Faaliyet oranları işletmenin sahip olduğu ve faaliyetlerini yürütmede kullandığı iktisadi kıymetlerin etkin ve verimli kullanılıp kullanılmadığını belirlemek için kullanılır. Bu oranlar satışlar ile çeşitli aktif değerler arasında uygun bir denge ve ilişki bulunduğunu varsayar. Bu oranların yüksek seyretmesi tercih edilen bir durumdur.

Tablo 4. Faaliyet (Varlk Kullanm) Oranlar

\begin{tabular}{|c|c|c|c|c|c|c|c|c|c|c|c|c|}
\hline \multirow{3}{*}{$\begin{array}{l}\text { Seçilmiş } \\
\text { Oranlar }\end{array}$} & \multicolumn{4}{|c|}{ BİM MAĞAZALARI } & \multicolumn{4}{|c|}{ CARREFOURSA } & \multicolumn{4}{|c|}{ MIGGROS } \\
\hline & \multicolumn{12}{|c|}{ Yillar } \\
\hline & 2015 & 2016 & 2017 & 2018 & 2015 & 2016 & 2017 & 2018 & 2015 & 2016 & 2017 & 2018 \\
\hline $\begin{array}{c}\text { Alacak Devir } \\
\text { Hız1 }\end{array}$ & 33,15 & 31,09 & 28,24 & 27,87 & 129,55 & 117,95 & 81,33 & 92,84 & 188,38 & 189,24 & 158,33 & 154,54 \\
\hline Stok Devir Hız1 & 14,98 & 14,93 & 14,11 & 12,68 & 4,76 & 6,22 & 5,63 & 6,11 & 6,521 & 6,681 & 5,90 & 5,99 \\
\hline Aktif Devir Hız1 & 4,18 & 4,02 & 3,53 & 3,61 & 1,29 & 1,49 & 1,40 & 1,96 & 1,65 & 1,76 & 1,49 & 1,72 \\
\hline $\begin{array}{c}\text { Net İşletme } \\
\text { Sermayesi Devir } \\
\text { Hiz1 }\end{array}$ & $-73,05$ & $-64,08$ & $-108,52$ & $-111,85$ & $-5,83$ & $-4,14$ & $-3,04$ & $-4,41$ & $-12,66$ & $-13,02$ & 8,82 & 8,50 \\
\hline $\begin{array}{c}\text { Maddi Duran } \\
\text { Varlık Devir } \\
\text { Hız1 }\end{array}$ & 9,77 & 9,60 & 8,10 & 8,74 & 4,71 & 6,75 & 5,95 & 8,22 & 7,69 & 8,72 & 4,10 & 4,85 \\
\hline
\end{tabular}

$\mathrm{Bu}$ hususlar dikkate alınarak Tablo 4 incelendiğinde;

Bir faaliyet dönemindeki kredili ya da net satışların ticari alacaklara bölünmesi suretiyle hesaplanan alacak devir hıəı alacakların yılda kaç kez tahsil edildiğini gösterir. Bu hız arttıkça alacakların paraya çevrilme derecesi artar. Ayrıca bu oranın büyümesi alacakların tahsil edilmesinde vadelerin kısaldığı anlamına gelir. Ticari alacakların ortalama tahsil süresi endüstri işletmelerinde 30 gün olarak kabul edilmektedir. Tabloya bakıldığında MIGROS firmasının alacak devir hızı diğer şirketlere kıyasla daha yüksektir. Alacaklar ile ilgili daba etkin politika iə̌ledig̈ini göstermektedir. Genel ortalamanın üzerinde olan CARREFOURSA firmas1 da alacaklar ile ilgili etkindir. Ancak BİM Mağazaları ise ortalamaya yakın olmakla birlikte diğer firmalara göre cok etkindir diyemeyiz. Bütün firmalarda son 2 yılda alacak devir hızları düşmüş olmasına rağmen oranın genel ortalamaya yakın ve üzerinde seyretmesi olumlu bir gelişmedir.

Yıllar itibariyle stok devir hızının büyüme seyrinde olması istenilen bir durumdur. Bu durum stok devir süresinin azalmasını ifade eder. Siparişlerin zamanında karşılanması kaydı ile stok devir hızının yüksek olması tercih edilen bir durumdur. Bu oranın yüksek seyretmesi nispi olarak stoklara daha az fon bağlanması anlamına gelir. Şirketler arasında kıyaslama yapıldığında BỉM Mağazalarının stok devir hızı diğer firmalara göre daha yükesektir ve stoklara daha az fon bağlamıştır. Fonlarm diğer alanlarda kullanarak kazancm arttrabilir. Sonra sıralama MIGROS ve CARREFOURSA şeklindedir.

Aktif devir hızı ise şirketlerin aktiflerinin kaç katı satış yaptıklarını gösterir. Bu oranın da yüksek seyretmesi olumludur. Ancak değerlendirme yaparken sektör ortalamasına da bakmak gerekir. Ayrıca değerlendirme yapılırken enflasyon oranlarının da dikkate alınması gerekir. Çünkü satışlar enflasyondan ciddi oranda etkilenirken aktif toplamı biraz geriden takip edebilir. Büyük endüstri işletmelerinde bu oranın 2 seviyesinde olması yeterli kabul edilirken küu̧ük endüstri işletmelerinde 2-4 arasında olması uygun olduğu ileri sürülmektedir. Tablo değerlendirildiğinde oran sıralamasında BİM MAĞAZALARI genel ortalamanın üzerinde, MIGROS VE CARREFOURSA firmaları ise altında gerçekleşmiştir. Bu durum MIGROS ve CARREFOURSA şirketleri için olumsuz olarak değerlendirilebilir.

Dönen varlıklar ile kısa vadeli yabancı kaynaklar arasındaki farkı ifade eden net işletme sermayesi (çalışma sermayesi) devir hızı, sermayenin ne kadar etkin kullanıldığını gösterir. Sermayenin yeterli olduğu durumlarda bu oranın yüksek olması olumlu bir durumdur. Ancak tablo incelendiğinde BìM ve CARREFOURSA marketlerinin 2015-18 yıllarındaki çalışma sermayelerinin yetersiz olduğu ve kısa vadeli borçların karşılamada finansal riskler taşıdığını söyleyebiliriz. MIGGROS marketinin ise ilk iki yıl için yetersiz olan çalşsma sermayesinin son iki yılda genel standardın altında olmasına rağmen kısa vadeli borçlarını karşılayabilecek düzeyde olduğunu söyleyebiliriz. Bu durumlar MIGGROS marketleri için finansal açıdan riskler taşıdığı gerçeğini değiştirmez. Tabloda çalışma sermayesi devir hızı yüksekliğinde sıralama 
BIM, MIGROS ve CARREFOURSA şeklindedir. Çalsma sermayesi ile yeterli düzeyde satıs yaptıklarm ifade edebiliriæ: Bu oran sektörden sektöre ve işletmeden işletmeye değişiklik gösterebilir. Kabul edilmiş genel bir oran bulunmamaktadır. Net satı̧sların net işletme sermayesinin üzerinde olması çalıs̆ma sermayesinin bütün market zincirlerinde etkin kullanuldı̆ğm ifade etmekle birlikte diğer göstergeler de dikkate alınırsa bu sermayenin yetersiz olduğu söylenebilir.

Maddi duran varlıkların faaliyet döneminde ne kadar etkin kullanıldığını gösteren maddi duran varlık devir hızının yüksek olması istenilen bir durumdur. Bu yükseklik maddi duran varlıkların kapasitelerinin üzerinde kullanıldığını da gösterebilir. 1 TL'lik maddi duran varlık bazında ne kadarlık satış yapıldığını gösteren bu oran konusunda kesin bir standart yoktur. Ancak endüstri işletmelerinde 5 seviyesinde olmasının uygun olacağı kabul edilir. Bu varlıklarda amorti işlemleri gerçekleştikçe orandaki yükselmenin artacağı dikkate alınmalıdır. Tablo incelendiğinde marketler açısından maddi duran varlkklarm en etkin kullanan firmanın BIMM marketi olduğu diğerlerinde ise oranın genel standardın üzerinde veya ona yakın olması maddi duran varlhklarn etkin kullanildğğm göstermektedir.

\section{İşletmelerin Mali Yapı (Kaldıraç) Oranları Açısından İncelenmesi}

Mali yapı oranları; işletme varlıklarının finansman şeklinin nasıl ve ne şekilde yapıldığını yani ne kadarlık kısmının yabancı ve ne kadarlık kısmının öz kaynaklar ile karşılandığını gösterirler. Yabancı kaynak ve öz kaynak arasında bir denge bulunup bulunmadığını tespit eden bu oranlar işletmenin borç ödeme gücünün ölçülmesi için de bir gösterge olduğundan hem mevcut ortaklar hem potansiyel ortaklar ve hem de işletmeye borç verenler açısından önemlidir. Ayrıca yöneticiler bu oranları kullanarak borçlanmanın işletmeye faydalı olup olmadığını belirler.

Tablo 5. Mali Yapı (Kaldirac) Oranlar

\begin{tabular}{|c|c|c|c|c|c|c|c|c|c|c|c|c|}
\hline \multirow{3}{*}{$\frac{\text { Seçilmiş Oranlar }}{\text { Oran Adı }}$} & \multicolumn{4}{|c|}{ BİM MAĞZALARI } & \multicolumn{4}{|c|}{ CARREFOURSA } & \multicolumn{4}{|c|}{ MİGROS } \\
\hline & \multicolumn{12}{|c|}{ Yillar } \\
\hline & 2015 & 2016 & 2017 & 2018 & 2015 & 2016 & 2017 & 2018 & 2015 & 2016 & 2017 & 2018 \\
\hline $\begin{array}{c}\text { Yabanc1 Kaynak } \\
\text { Oranı }\end{array}$ & 0,599 & 0,619 & 0,579 & 0,608 & 0,734 & 0,876 & 0,979 & 0,980 & 0,917 & 0,969 & 0,852 & 0,942 \\
\hline $\begin{array}{l}\text { Öz Kaynak } \\
\text { Oranı }\end{array}$ & 0,401 & 0,381 & 0,421 & 0,392 & 0,266 & 0,124 & 0,021 & 0,020 & 0,083 & 0,031 & 0,148 & 0,058 \\
\hline $\begin{array}{c}\text { Yabancı Kaynak } \\
\text { - Öz Kaynak } \\
\text { Oranı }\end{array}$ & 1,495 & 1,624 & 1,375 & 1,548 & 2,756 & 7,073 & 46,314 & 48,745 & 11,028 & 31,587 & 5,746 & 16,139 \\
\hline $\begin{array}{l}\text { Yabanc1 Kaynak } \\
\text { Vade Yap. Oranı }\end{array}$ & 0,961 & 0,961 & 0,942 & 0,944 & 0,745 & 0,802 & 0,869 & 0,925 & 0,521 & 0,546 & 0,629 & 0,651 \\
\hline $\begin{array}{l}\text { Kısa Vd. Yab. } \\
\text { Kaynak Oranı }\end{array}$ & 0,576 & 0,595 & 0,545 & 0,573 & 0,547 & 0,703 & 0,850 & 0,906 & 0,477 & 0,529 & 0,535 & 0,613 \\
\hline $\begin{array}{l}\text { Uzun Vad. Yab. } \\
\text { Kaynak Oranı }\end{array}$ & 0,024 & 0,024 & 0,034 & 0,034 & 0,187 & 0,173 & 0,129 & 0,074 & 0,439 & 0,440 & 0,316 & 0,328 \\
\hline $\begin{array}{c}\text { Duran Varlık / } \\
\text { Öz Kaynak }\end{array}$ & 1,202 & 1,228 & 1,157 & 1,169 & 2,540 & 5,296 & 28,960 & 26,821 & 7,849 & 19,757 & 4,274 & 10,094 \\
\hline
\end{tabular}

Bu hususlar dikkate alındığında Tablo 5'deki veriler şöyle değerlendirilebilir:

Yukarıdaki oranlardan ilk üçü işletmenin mali yapısını ana hatları ile gösteren ve aslında aynı durumu farklı açılardan ifade eden oranlardır. Toplam yabancı kaynak oranı ile öz kaynak oranlarının genel standardı 0,50 'dir. Ancak gelişmekte olan ülkelerde sermaye yetersizliği ve borçlanmanın avantajı olması sebebiyle yabancı kaynak oranının 0,50'nin üzerinde, öz kaynak oranı da 0,50'nin altında olduğu görülmektedir. Yabancı kaynak/öz kaynak oranının 1 olması genel standarttır. Ancak öz kaynağın kıt olduğu ülkelerde bu oranın 1'in üzerinde seyrettiği bilinmektedir. İşletmelerin alacak devir hızı yüksek, satışları düzenli ve nakit girişleri sürekli ve düzenli ise varlıklarının likiditesi yüksek ise oranın 1'den büyük olması normal karşılanabilir. Ekonomide durgunluk varsa oranın 1'den büyük olması işletmeyi mali açıdan başarısızlı̆̆a uğratabilir.

Bu bağlamda tabloda genel standartlara en yakın değerler BİM şirketine ait olduğu söylenebilir. Her ne kadar genel standardın alında olsa bile mali yapıyı oluşturan yabancı kaynak ve öz kaynak unsurlarında bir denge gözetilmiştir. Bu durum mali yapısının güçlü olduğunu göstermektedir. Enflasyonun yüksek seyrettiği bu yıllarda öz kaynak payının standartların altında seyretmesi kabul edilebilir bir durumdur. 
CARREFOURSA şirketinin ilk 2 yll az da olsa sürdürülebilir bir mali yapıyı oluştururken son 2 yılda bu durum çok büyük oranda ve borçlanma artarak olumsuz yönde değişmiştir. Bu durumda mali yap k kredi kuruluşları açısından riskli hale gelmiştir. Ancak sirket yöneticileri yabancı kaynak oramm yükesek tutup kaldrrac

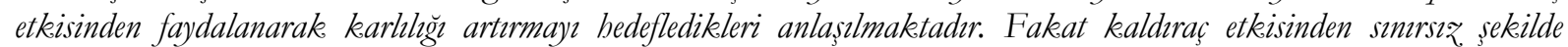
faydalanma imkâm da yoktur. Yabancı kaynak maliyeti öz. kaynak maliyetini assyyorsa borçlanma avantaji ortadan kalkar. Finans yöneticisi emniyet ve yüksek kar sağlama ile zarar riski arasinda bir denge sağlamalddr. Kanaatimiz̨e bu durum dikkate alnmamıs ve karlllkta bir artıs görünmemekte ve mali yapı riski devam etmektedir. MİGROS șirketinin de öz kaynak yapısı ciddi oranda zaynf görünmektedir. Ağrrlk borçlanma yönündedir ve mali yapısmm kredi kuruluslan açssindan riskli olduğu söllenebilir.

Toplam yabancı kaynaklar içerisinde kısa vadeli borçların oranının genel standardı 2/3 olmasının kabul edilebilir olduğu ileri sürülmektedir. Kısa vadeli borçların vade yapısı bakımından durumu en iyi olan firmanın MIGGROS firması olduğu Tablo 5'den görülmektedir. Bu firmanın kısa vadeli borçlarının toplam borçlar içerisindeki payı 2015 ve 2016 yllarında \%52 ve \%54 düzeyindedir. Bu durum uzun vadeli borçlanma imkânının (kredi ve diğer borçlanma yönünden) iyi olduğunu göstermektedir. 2017 ve 2018 yıllarında oran yükselmiş olmasına rağmen yine de genel standardın altında kalmıştır. Cari oran ile birlikte

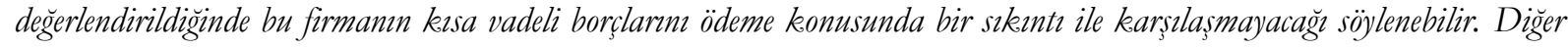
iki firmann kessa vadeli borçlarmm toplam borçlar içindeki paymmn genel standardin üstünde olduğu görülmektedir. Uzun vadeli borçlanma konusunda sıkentr yaşadıklar ifade edilebilir. Kısa vadeli yabanc kaynakta geri ödeme riski artmıştr. Bu firmalara ait cari oranlar da dikekate alundiğnda kısa vadeli borrglarm karşılama bakımından en zayıf firmanun CARREFOURS A firması olduğu söylenebilir.

Kısa vadeli yabancı kaynağın pasif toplamı içindeki payının genel standardının 1/3 olması normal karşılanabilir. Toplam aktiflerinin ne kadarlık kısmının kısa vadeli yabancı kaynaklar ile karşılandığını gösteren kısa vadeli yabancı kaynak oranı arttıkça borç geri ödeme riski de artmış olur. Özellikle uzun vadeli varlık finansmanında kısa vadeli yabancı kaynaklar kullanılırsa bu risk daha da artacaktır. Ancak uzun vadeli kredi temininde sıkıntıların yaşandığı ve sermaye piyasasının yeterince gelişmemiş olduğu ülkemizde oran genellikle $1 / 3$ 'ün üzerinde ve hatta $\% 50$ civarında olmaktadır. İşletmelerin ödeme darboğazına girmemeleri için özellikle duran varlıklarını kısa vadeli yabancı kaynaklar ile finanse etmemeleri gerekir. İşletmelerin varlıklarının ne kadarlık kısmının uzun vadeli borçlar ile finanse edildiğini gösteren uzun vadeli yabancı kaynak oranı genellikle sabit yatırımların finansmanında kullanılır. Bu oranın normal şartlarda 1/6 olması idealdir. Ancak kısa vadeli yabancı kaynak oranını düşürmek maksadıyla oranın yükselmesi kabul edilebilir bir durumdur. Bir diğer husus da fiyatlar genel seviyesinin yükseldiği dönemlerde enflasyon oranı kadar borçlanma maliyeti düşmektedir. Bu bağlamda Tablo 5' de firmalara ait yabancı kaynak yapısı değerlendirildiğinde:

MİGROS firmasının kısa vadeli borçlarının diğer firmalara göre daha düşük olduğu ancak normal sınırın üzerinde olduğu görülmektedir. Uzun vadeli borçlanma yönünden de oran yine normal sınırların üzerindedir. Her iki oran birlikte değerlendirildiğinde firmanın borçlanma oranları yüksek, öz kaynak oranı düşüktür. Genel standartlara bakıldığında; mevcut ortaklar, potansiyel ortaklar ve kredi kuruluşları açısından firmann mali yapısınnn riskeli olduğu söylenebilir.

BİM firmasının kısa vadeli yabancı kaynak oranı normal sınırın üzerinde ancak uzun vadeli borçlanma oranının normal sınırın çok altında olduğu görülmektedir. Firmanın mali yapısı açısından öz kaynakları ise diğer firmalara kıyasla yeterli görülmektedir. Kısa vadeli borçlarını çevirebildiği ölçüde mali yapının çok riskli olmadiğ söylenebilir.

CARREFOURSA firmasının kısa vadeli borçlanma oranları genel standartların çok üzerinde uzun vadeli borçlanma oranları ise altındadır. Ancak firmanın öz kaynak oranı genel standartların çok altında olması sebebiyle mali yapısımn riskli olduğu değerlendirilmektedir.

Duran varlıkların ne kadarlık kısmının öz kaynaklar ile finanse edildiğini gösteren duran varlık $\ddot{z} z$ kaynak oranının genel standardının 1(bir) olması arzu edilen bir durumdur. Oranın 1'den büyük olması bu varlıkların finansmanında yabancı kaynakların da kullanıldığını gösterir. Bu bağlamda tablo 5 'deki 4 yıl birlikte değerlendirildiğinde MIGROS ve CARREFOURS A firmalarmm bu oran istenilen durumdan cok yüksek olduğu görülmektedir. Bu durum öz kaynaklarmm yetersizliğini de gösterir. BIM firmasmm oran da arž edilen seviyenin

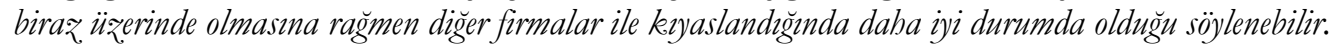




\section{İşletmelerin Karlı1ık Oranları Açısından İncelenmesi}

İşletme varlıklarının ne kadar etkin ve verimli yönetildiği, yönetimin başarısı, gelecekteki firma değerinin nasıl şekilleneceği ve hisse senetlerinin değerinin tahmin edilmesi gibi konular hakkındaki nihai bilgiler karlılık oranları aracılığı ile sağlanır ve alınan birçok karar ve uygulanan politikaların net sonucu da karllılı ile ölçülür. Karlılık oranları ile yönetim, işletme sahipleri, kredi kuruluşları, potansiyel yatırımcılar, çalışanlar ve devlet yakından ilgilidir. İşletmelerin yatırımlardan yüksek karlılık sağlaması oto finansman olarak adlandırılan kaynak teminini ifade eder. Karlılık oranları genellikle; satışlar, öz kaynaklar ve varlıklar üzerinden ifade edilir. Karlılık oranlarında yıllar itibariyle artışın olması işletme lehine yorumlanır. Ancak istenilen durum; kar marimn düsük fakat satıslarn fazla olmasıdrr. Cünkü kar marjinn yüksek olması o islletmenin fazla tutarda kar ettiği anlamma gelmez. Bununla birlikte karllhk oranlarmm yeterli olup olmadiğl; alternatif yatirm alanlar, sektör ortalamalar, ben₹er ișletme oranlar, işletmenin kar beklentisi ve ekonomik șartlar dikkeate almnarak. değerlendirilmelidir.

Gelir tablosunda hesaplama bakımından farklı kar bölümleri vardır. Bu bölümler dikkate alınarak sonuçlar yorumlanır. Bunlardan ilki satış kar marjı (brüt satış karı) oranıdır. Bu oran üzerinde enflasyon pek etkili olmaz. Çünkü pay ve paydadaki her iki unsur da aynı şekilde etkilenir.

Tablo 6. Karllhk Oranlar

\begin{tabular}{|c|c|c|c|c|c|c|c|c|c|c|c|c|}
\hline \multirow{3}{*}{$\frac{\text { Seçilmiş Oranlar }}{\text { Oran Ad1 }}$} & \multicolumn{4}{|c|}{ BİM MAĞZALARI } & \multicolumn{4}{|c|}{ CARREFOURSA } & \multicolumn{4}{|c|}{ MİGROS } \\
\hline & \multicolumn{12}{|c|}{ Yillar } \\
\hline & 2015 & 2016 & 2017 & 2018 & 2015 & 2016 & 2017 & 2018 & 2015 & 2016 & 2017 & 2018 \\
\hline Brüt Kar Oranı & 0,162 & 0,168 & 0,171 & 0,177 & 0,256 & 0,226 & 0,256 & 0,250 & 0,269 & 0,268 & 0,266 & 0,280 \\
\hline Faaliyet Karı Oranı & 0,041 & 0,040 & 0,043 & 0,048 & 0,012 & $-0,086$ & $-0,036$ & $-0,047$ & 0,028 & 0,031 & 0,020 & 0,024 \\
\hline Net Kar Oranı & 0,033 & 0,033 & 0,035 & 0,039 & $-0,008$ & $-0,096$ & $-0,067$ & $-0,002$ & $-0,040$ & $-0,027$ & 0,033 & $-0,045$ \\
\hline $\begin{array}{c}\text { Öz Kaynak Karlılık } \\
\text { Oranı }\end{array}$ & 0,349 & 0,353 & 0,292 & 0,356 & $-0,039$ & $-1,154$ & $-4,458$ & $-0,216$ & $-0,793$ & $-1,558$ & 0,336 & $-1,316$ \\
\hline Aktif Karlılık Oranı & 0,180 & 0,170 & 0,156 & 0,182 & $-0,010$ & $-0,177$ & $-0,109$ & 0,011 & $-0,061$ & $-0,036$ & 0,058 & $-0,096$ \\
\hline
\end{tabular}

Bu zaviyede Tablo 6 değerlendirildiğinde;

MİGROS firmasının normal faaliyet konusunu oluşturan satış kar marjı diğer firmalara göre daha yüksektir. Ayrıca yıllar itibariyle istikrarlı bir oran yakaladığını da söyleyebiliriz. CARREFOURSA firması da benzer bir durum yakalamıştır. Satış kar marjı için standart bir oran olmamasına rağmen, bu market zincirlerinin BİM firmasına nazaran satış karlılık oranları daha iyi düzeydedir. Bu durum BİM firmasına göre toplam satışlar içindeki satulan mallarn maliyetini daha iyi kontrol altunda tuttuklarm ifade etmekte ve rekabet avantaji sağlamaktadırlar șeklinde yorumlanabilir. Ancak ürün satıs fiyatlarmnn yüksekekiğini de ifade edebilir.

Faaliyet kar oranı satışlar üzerinden faaliyet karlılı̆̆ını gösterir ve işletmenin ana faaliyetlerinin ne ölçüde karlı olduğunu ifade eder. Orann yükesekliüi işletmenin esas faaliyetinin karl ve verimli olduğn yönünde yorumlanır. Oranın azalma eğiliminde olması karllhk ve verimliliğin azaldiğm gösterir. Oranın ne kadar iyi olduğu geçmiş dönemler, benzer işletmeler ve sektör ortalamaları ile anlaşılır. Oranın yüksekliği yanında değerlerin tutarları da önemlidir.

Bu bağlamda tablo değerlendirildiğinde; brüt kar marjı BİM firmasına nazaran ciddi oranda yüksek olan MIGROS ve CARREFOURSA firmalarının faaliyet giderlerinin son dört yl boyunca BİM firmasına göre yüksek olduğu anlaşılmaktadır. Bu durum faaliyet karlılığını olumsuz yönde etkilemiştir. Araştırma ve geliştirme, pazarlama satış ve dağıtım ve genel yönetim giderlerinin yüksekliğinin sebepleri araştırılmalı ve gözden geçirilmelidir. Faaliyet karlılığı oranı (tutarlar da dikkate alınsa) bakımından durumu en iyi olan firma BIM market zinciri olduğn görülmektedir. Bu firma faaliyet giderlerini yllar itibariyle kontrol altında tutmuştur. Bu durum ise faaliyet karlllığ üzerinde olumlu etki yapmıştır. Aynı durum MİGROS firması içinde geçerli olmakla birlikte faaliyet giderleri düzeyinin nispeten yüksek olması brüt kar marjı ile faaliyet karlhlğg arasinda önemli farkhlhk oluşturmuștur. CARREFOURSA firmasının ana faaliyet konusu ile ilgili 
karll1ık oranı 2015 yllında pozitif olmasına rağmen sonraki yıllarda faaliyet giderlerinin kontrolü bakımından bir olumsuzluk yaşadığı ve bu durumun da faaliyet karlhlğm olumsuz sekeilde etkilediği görülmektedir.

İşletmelerin uyguladıkları politika ve kararların sonucu ve faaliyetlerinin net verimliliğini ölçme konusunda bilgi veren net kar oranının yüksekliği olumlu bir durumdur. Karlılı̆̆ın tutarının da önemli olduğu bir gerçektir. Büyük endüstri işletmelerinde bu oranın \%4-6 arasında olmasının uygun olacağı ileri sürülmektedir.

$\mathrm{Bu}$ hususlar dikkate alındığında net kar oranı bakımından durumu en olumsuz olan firmalar CARREFOURSA ve MIGROS firmalarıdır. Oranlara bakıldığında MİGROS firmasının 2017 yılı hariç bu firmalar 2015-18 yılları arasında faaliyetlerini zarar ile kapatmışlardır. Bu sebeple oranlar negatif çıkmıştır. Oranın negatif çıkması bu firmalarda diğer faaliyet, finansman ve olağandışı giderlerin diğer faaliyet gelirlerinden yüksek olduğunu da göstermektedir. Bu durum verimlilik ve karllllk üzerinde olumsuz etkiyi artırmıştır. Belirtilen giderler üzerinde anılan firmalar daha ciddi tedbirler almalıdırlar. Çünkü işletme ile ilgili taraflar genellikle bu oran ile işletmeyi değerlendirir.

Tablo değerlendirildig̈inde net kar oran en iyi olan firmann (\%3-4 arasi) BİM firması olduğu görülmektedir. Oranın faaliyet karlhluğ orannna göre düsmesi diğger giderler ile finansman giderlerinin diğer gelirlerden fazla olması ve vergiye bağğ olarak açılanabilir. Bu durum firmanin varlkklarm verimli kullandiğg şeklinde yorumlanabilir.

İşletmeye ortaklarca tahsis edilen değerlerin hangi ölçüde etkin ve verimli kullanıldığını tespit etmek amacıyla öz kaynak karlılığı oranı kullanılır. İşletmeye yatırım yapmış ortakların yatırdıkları değerler karşllı̆ında her bir birim için ne oranda kar sağladığı bu oran sayesinde tespit edilir. Bu oranın yüksek olması istenilen bir durumdur. Fiyatlar genel seviyesinin yıllar itibariyle artış/azalış göstermesi oran üzerinde etkili olur. Çünkü dönem net karı enflasyondan doğrudan etkilenirken öz kaynaklar içindeki sermaye kalemi nispi bir durağanlığı sebebiyle öz kaynaklar enflasyonu geriden takip eder. Bu durumda oran zaman içinde büyüme eğilimi gösterebilir. Sermaye artırımının olduğu yıllarda oran küçülebilir. Bu oranın değerlendirmesi yapılırken bu hususlara dikkat etmek gerekir.

Bu bilgiler bazında tablo 6'ya bakıldığında MİGROS firması (2017 ylı hariç) ile CARREFOURSA firmasının 2015-18 yılları arasında zarar etmiş olması öz kaynak karlılığını olumsuz yönde etkilemiştir. Bu durumda bu market zincirlerine yatırım yapmış olan yatırımcılar şirket faaliyetlerinde ciddi manada zarar ile karşılaşmışlardır. Ortaya çıkan zarar, market zincirlerinin öz kaynaklarının toplam kaynaklar içerisindeki payının azalmasına da yol açmışır. Bu duruma; şirketin yabancı kaynak finansmanına ağırlık vermesi de yol açmış olabilir. Şirket ortakları ya sermaye artırımına giderek ya da zarar ortaklar tarafindan veya yedekler ile karşılanarak toplam kaynaklar içindeki öz kaynak payı korunabilir.

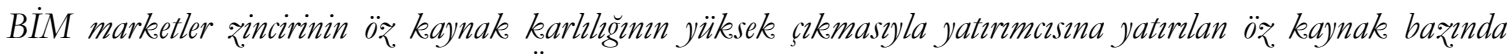
\%30'larda kazanc săgladiğg görülmektedir. Öz. kaynak tutarmin az olmast ya da dură̆anliğ sebebiyle enflasyondan fąlaca etkilenmesi, orann yükesek çımasinda etkili olabilir. Ancak firmann öz kaynak tutar diğer firmalara göre daha yüksektir.

İşetme aktiflerinin ne ölçüde karlı kullanıldığını tespit etmek amacıyla aktif karlılık oranı kullanılır. Öncelikli olarak işletmelerin karlılıklarını artırabilmeleri için net satışların artırılması ve buna bağlı olarak maliyet ve gider kalemlerinin mümkün olan en alt seviyeye çekilmesi gerekir. Aynı satış ve karlılık rakamlarının daha düşük yatırımlarla karşılanması ve atıl olarak varlık bulunmaması bu oranın yükselmesini sağlayacaktır. Vergi tutarının işletme kontrolünde olmaması ve vergi uygulamalarından işletmelerin farklı etkilenmesi gibi sebepler ile kar rakamı olarak vergi öncesi dönem karı rakamının kullanılması daha uygundur.

Bu bususlar dikkate alindiğnda Tablo 6'da aktif karllhk oran en iyi olan firma BİM marketter zinciridir. Her bir

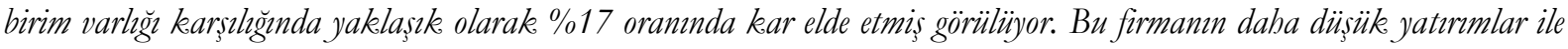
daba yülksek kar elde ettiği söylenebilir. Diğer firmalara göre atıl yatirm yapmama konusunda daha başarnlider. Oranın yüksek olması firma varlık değerlerinin düşük olması ile de ilgili olabilir. Ancak varlık değeri bakımından CARREFOURSA firmasından çok iyi, MİGROS firmasına da yakın düzeyde olduğu mali durum tablosundan anlaşılmaktadır.

2015-18 yıllar1 arasında aktif karlilı oranı bakımından durumu en zayıf olan firmanin CARREFOURSA olduğu görülmektedir. Anılan tarihler arasında bu firmanın zarar etmesi aktif karlılığının da olumsuz çıkmasına yol açmıştır. MIGGROS firmasının 2017 yılı hariç anılan yıllarda zarar etmiş olması aktif karlılık oranını olumsuz etkilemiş̧ir. Her iki firmanın da zarar etmesinin yanında aymı sektördeki diğer firma ile karşılasstırldı̆ğnda varlıklarını etkin ve verimli kullanamadığı şeklinde değerlendirme yapılabilir. 


\section{Sonuç}

Küreselleşmenin etkisiyle iletişim hızla artmakta, teknolojik değişimler yaşanmakta ve tüketici talepleri işletmeleri müşteri odaklı bir yönetime zorlamaktadır. Gıda perakende sektörü de yaşanan bu gelişmelere ayak uydurarak pazardaki payını gün geçtikçe artırmaktadır. Bunun en önemli sebebi bu sektörde ciddi bir rekabet ortamının varlığıdır. Yoğun rekabet ortamında hareket eden gida perakende işletmelerinin artan faaliyet hacmi ekonomiye olumlu yönde bir katma değer sağlayacaktır. Bir ülke ekonomisi için, sağlıklı ve dinamik işleyen bir gıda perakende sektörü ise iktisadi kalkınma ve sanayileşme sürecinin önemli bir tamamlayıcısı olacaktır. Emeğin yoğun olarak kullanıldığı gıda perakende sektörü, tarımsal ürünlerin değerlendirilmesini, sanayiye hammadde teminini, istihdamın artırılmasını ve halkın sağlıklı beslenmesini sağladığı için dünyada tüm ülkeler tarafindan sosyo-ekonomik açıdan önem arz etmektedir.

Bu çerçevede araştırmada, BIST-Perakende Ticaret Sektörü'nde işlem gören 3 market zincirinin (BIM, MIGROS, CARREFOURSA) finansal analiz türlerinden oran analizi yöntemiyle finansal performansları tespit edilmeye çalışılmıştır. BIST-Perakende ve Ticaret Sektörü'nde 12 perakende işletmesi bulunmaktadır. Bu işletmelerden; BIM, MIGROS ve CARREFOURSA firmaları da bu sektörde market zinciri olarak faaliyet göstermektedir. Çalışmada market zincirlerinin kamuoyuna açıkladığı ve bağımsız denetimden geçmiş 2015-2018 yıllarına ait olan IMKB'de yayımlanmış finansal tabloları kullanılmıştır. BIST’te Gıda Sektöründe işlem gören 12 perakende firması içerisinde ilgili dönemler için verilerini düzenli olarak elde edilen 3 firmanın mali tabloları analizde kullanılmıştır.

Araştırma sonucunda firmalar düzeyinde aşağıda özetlenen bulgular şöyledir:

Şirketler karşılaştırıldığında nispi olarak cari ve likidite oran yükseklik düzeyi sıralaması MİGROS, BİM MAĞAZALARI ve CARREFOURSA olarak gerçekleşirken, BIM ve CARREFOURSA firmalarının nakit oranları genel standarda yakın olarak izlenmiştir. Bu üç oran birlikte değerlendirildiğinde 3 firmanın nakit oran düzeyleri yeterli olsa bile kısa vadeli borçlarını ödeme konusunda riskli oldukları söylenebilir.

MIGROS firmasının alacak devir hızı diğer şirketlere kıyasla daha yüksektir. BİM Mağazalarının stok devir hızı diğer firmalara göre daha yüksektir ve stoklara daha az fon bağlamıştır. Aktif devir hızına bakıldığında BIM MAĞAZALARI genel ortalamanın üzerinde, MIGROS VE CARREFOURSA firmaları ise altında gerçekleşmiştir. MİGROS marketinin ise ilk iki yıl için yetersiz olan çalışma sermayesinin son iki yılda genel standardın altında olmasına rağmen kısa vadeli borçlarını karşılayabilecek düzeyde olduğu söylenebilir. Çalışma sermayesi devir hızı yüksekliğinde sıralama BIM, MİGROS ve CARREFOURSA şeklindedir. Çalışma sermayesi ile firmaların yeterli düzeyde satış yaptıklanı ifade edilebilir. Maddi duran varlıklarını en etkin kullanan firmanın BİM firması olduğu diğerlerinde ise oranın genel standardın üzerinde veya ona yakın olması maddi duran varlıkların etkin kullanıldığını göstermektedir.

Firmaların mali yapı oranlarına bakılacak olursa; genel standartlara en yakın değerler BİM firmasına ait olduğu söylenebilir. Her ne kadar genel standardın altında olsa bile mali yapıyı oluşturan yabancı kaynak ve öz kaynak unsurlarında bir denge gözetilmiştir. Kısa vadeli borçların vade yapısı bakımından durumu en iyi olan firmanın MİGROS firması olduğu görülmektedir. Kısa vadeli borçlarını karşlama bakımından en zayıf firmanın CARREFOURSA firması olduğu söylenebilir. MİGROS firmasının kısa vadeli borçlarının diğer firmalara göre daha düşük olduğu ancak normal sınırın üzerinde olduğu görülmektedir. Uzun vadeli borçlanma yönünden de oran yine normal sınırların üzerindedir. Her iki oran birlikte değerlendirildiğinde firmanın borçlanma oranları yüksek, öz kaynak oranı düşüktür. Genel standartlara bakıldığında; mevcut ortaklar, potansiyel ortaklar ve kredi kuruluşları açısından firmanın mali yapısının riskli olduğu söylenebilir.

BİM firmasının kısa vadeli yabancı kaynak oranı normal sınıın üzerinde ancak uzun vadeli borçlanma oranının normal sınırın çok alında olduğu görülmektedir. CARREFOURSA firmasının kısa vadeli borçlanma oranları genel standartların çok üzerinde uzun vadeli borçlanma oranları ise altındadır. Ancak firmanın öz kaynak oranı genel standartların çok altında olması sebebiyle mali yapısının riskli olduğu değerlendirilmektedir. MIGROS ve CARREFOURSA firmalarının duran varlık öz kaynak oranı istenilen durumdan çok yüksek olduğu görülmektedir.

MIGGROS firmasının normal faaliyet konusunu oluşturan satış kar marjı diğer firmalara göre daha yüksektir. Faaliyet karlılığı oranı bakımından durumu en iyi olan firma BİM market zinciri olduğu görülmektedir. Net kar oranı bakımından durumu en olumsuz olan firmalar CARREFOURSA ve MIGROS şirketleridir. MIGROS firması (2017 yılı hariç) ile CARREFOURSA firmasının 2015-18 yılları arasında zarar etmiş olması öz kaynak karlılığını olumsuz yönde etkilemiştir. Aktif karllık oranı en iyi olan 
firma BİM Marketler zinciridir. Aktif karllık oranı bakımından durumu en zayıf olan firmanın CARREFOURSA olduğu görülmektedir.

Gıda marketleri piyasasında; MIGROS ve CARREFOURSA marketlerinden genellikle orta ve yüksek gelir düzeyine sahip müşterilerin alış veriş yaptığı ve BİM market zincirinden ise orta ve alt gelir düzeyine sahip müşterilerin alış veriş yaptığı ve ürün fiyatlarının BİM marketlerinde MIIGROS ve CARREFOURSA marketlerine göre daha uygun fiyatla satıldığı algısı vardır. Fakat çalışmada Gıda perakende sektöründe orta ve yüksek gelir düzeyine sahip müşteri kitlesinin firma verimliliği ve karlllığına olan katkısı düşük, orta ve alt gelir düzeyine sahip müşteri kitlesinin firma verimliliği ve karlılığına olan katkısı yüksek çıkmıştır. Bu durumun sebepleri olarak BİM market zincirinin şube sayısının fazla olması sebebiyle müssterilerin daha kolay ulaşabilmesi ve fiyat politikasının müşterilere daha uygun gelmesinden dolayı daha fazla satış yapmaktadır. Bunun sonucu olarak piyasada kar marjı düşük satış tutarı yüksek bir politika anlayışının firmanın verimliliği ve karlılığına olumlu katkı sağladığı öngörülebilir.

\section{Etik Beyan}

"Türkiye'de Gıda Perakendeciliği Sektöründe Finansal Analiz ve Bir Uygulama” başlıklı çalışmanın yazım sürecinde bilimsel kurallara, etik ve alıntı kurallarına uyulmuş; toplanan veriler üzerinde herhangi bir tahrifat yapılmamış ve bu çalışma herhangi başka bir akademik yayın ortamına değerlendirme için gönderilmemiştir.

\section{Kaynaklar}

Akın, F. ve Ece, N. (2013). İMKB'de işlem gören sigorta şirketlerinin 2006- 2010 dönemi finansal performanslarının analizi. Mubasebe ve Finansman Dergisi, 57, 89-106. Erişim adresi: https://dergipark.org.tr/tr/download/articlefile/427026

Bodur, A. (2006).Oranlar aracilı̆̆ ile finansal durumunuzu nasıl çözümlersiniz? "Küçük işletmeler için bir rehber". Journal of Yasar University, 1(1), 49-67. Erişim adresi: https://dergipark.org.tr/tr/download/article-file/179111

Çabuk, A. ve Lazol, İ. (2009). Mali tablolar analizi. Bursa: Ekin Basım Yayın Dağıtım.

Çalıs, Y. E., Ünal, İ. H., Güven, B. ve Çanakçı, S. (2018). Borsa İstanbul'da faaliyet gösteren lokanta ve oteller sektörünün finansal durum ve performanslarının değerlendirilmesi. Ușak Üniversitesi Sosyal Bilimler Dergisi, 11, 293-318. Erişim adresi: https://dergipark.org.tr/tr/download/article-file/634194

Çetiner, E. (2007). İşletmelerde mali analiz. Ankara: Gazi Kitapevi.

Dimitropoulos, P. (2010). The financial performance of the Greek football clubs. Sport Management International Journal, 6(1), 5-28.

Dumanoğlu, S. ve Ergül, N. (2010). İMKB'de işlem gören teknoloji şirketlerinin mali performans ölçümü. Muhasebe ve Finansman Dergisi, (48), 101-111. Erişim adresi: http://journal.mufad.org.tr/index.php?option

Guo, L. ve Wang, Z. (2019). Ratio analysis of J Sainsbury plc financial performance between 2015 and 2018 in comparison with Tesco and Morrisons. American Journal of Industrial and Business Management, 9, 325-341. Erişim adresi: https://file.scirp.org/pdf/AJIBM_2019022616491346.pdf

Gümüss, U. T. ve Bolel, N. (2017). Rasyo analizleri ile finansal performansin ölçülmesi: Borsa İstanbul'da faaliyet gösteren havayolu şirketlerinde bir uygulama. Adnan Menderes Universitesi Sosyal Bilimler Enstitiisü Dergisi, 4(2), 8796. Erişim adresi: https://dergipark.org.tr/tr/download/article-file/339693

Karadeniz, E., Dalak, S., Beyazgül, M. ve Günay, F. (2016). Konaklama ve yiyecek hizmetleri alt sektöründeki küçük, orta ve büyük ölçekli işletmelerin finansal performansının karşılaştırmalı tablolar analizi tekniği ile incelenmesi. Mubasebe Bilim Dünyası Dergisi, 18(3), 631-657. Erişim adresi: http://eds.b.ebscohost.com/eds/pdfviewer/pdfviewer?

Karadeniz, E., Koşan, L. ve Kahiloğulları, S. (2014). Borsa İstanbul'da işlem gören spor şirketlerinin finansal performansının oran yöntemiyle analizi. C..Ü. Sosyal Bilimler Enstitïsï Dergisi, 23(2), 129-144. Erişim adresi: https://dergipark.org.tr/tr/download/article-file/362621

Karahan, N. S. (2014). Türkiye'de gıda perakendecilig̈i sektöründe finansal analiz ve bir uygulama (Yüksek Lisans Tezi). Marmara Üniversitesi Sosyal Bilimler Enstitüsü, İstanbul.

KPMG (2018). Perakende Sektörel Bakış 2018. Erişim adresi: https://assets.kpmg/content/dam/kpmg/tr/pdf/2018/01/sektorelbakis-2018-perakende.pdf

Levy, M. ve Weitz, B. A. (2004). Retailing management. New York: MacGraw-Hill/Irwin.

Musa A. ve Göğebakan M. C. (2003). Yeniden değerlendirme oranın finansal analiz üzerindeki etkisi. Bankaccllk. Dergisi, 45, 61-80. Erişim adresi: https://www.tbb.org.tr/dosyalar/dergiler/dokumanlar/45.pdf

Öğünç, H. (2018). Gıda ve tekstil sektörlerinin karşılaştırmalı finansal analizi (2014-2016 dönemi), MAKÜ-BİFD, 1(1), 53-70. Erişim adresi: https://dergipark.org.tr/tr/download/article-file/574884

Önal, S., Mat, M. ve Eroğlu, S. E. (2018). Hava taşımacillğı işletmelerinin karlllık analizi: Türkiye ve Avrupa sektör karşılaştırması. Türkiye Sosyal Araştrmalar Dergisi, 22(3), 721-744. Erişim adresi: https://pdfs.semanticscholar.org/5307/252738f78c221f937f55dd50a1d682c03391.pdf 
Schmidgall, R. ve Defranco, A. (2004). Ratio analysis: financial benchmarks for the club industry. Journal of Hospitality Financial Management, 12(1), 1-15.

Steed, E., Brody, R. G. ve Gu, Z. (2003). Financial performance related to accounting treatments at hotels with breakfast included: A case analysis. The Journal of Hospitality Financial Management, 11(1), 87-96.

Şen L., Zengin, B. ve Yusubov F. (2015). Otel işletmelerinde finansal analizlere ilişkin bir örnek olay incelemesi. İsletme Bilimi Dergisi, 3(1), 64-85. Erişim adresi: https://dergipark.org.tr/tr/pub/jobs/issue/22920/245426

Yağlıca, H. (2006). Hafif sanayiye dayal sektörlerin trend analiz̨: iso 500 ömeği (Bitirme Projesi) Doğuş Üniversitesi İktisadi ve İdari Bilimler Fakültesi, İstanbul.

Yenisu, E. (2019). Finansal tabloların oran analizi ile incelenmesi Adese örneği. Aksaray Üniversitesi Sosyal Bilimler Enstitüsü Dergisi (ASED), 3(1), 20-45.

Yılmaz, E. ve Tunay, A. (2018). Oran analizi yöntemi ile konaklama ve yiyecek hizmetleri alt sınıfındaki küçük, orta ve büyük ölçekli işletmelerin finansal performanslarının karşılaştırmalı analizi. Mubasebe ve Maliye Dergisi, 1(2), 37 -

52. Erişim adresi: http://www.idaacademia.org/tr/download/article-file/528054

http://www.tuik.gov.tr/VeriTabanlari.do?vt_id=28\&ust_id=null

https://www.bim.com.tr/default.aspx

https://www.migroskurumsal.com/

https://www.carrefoursa.com/tr/

https://www.ekonomist.com.tr/perakende/gida-perakendesinde-format-savasi-hizlandi.html

\section{EXTENDED ABSTRACT}

The food retail industry, which is one of the sectors with intense competition, has the highest share in the retail market. In recent years, the small food shops in the neighborhoods lost their places to largescale stores. The neighborhoods, which these stores cannot penetrate, are now considered as a market place and one of the places, where the competition is at a high level. For this reason, the food retailers utilize all the sources they have in order to establish new store chains. These retailers located between the smallest food markets and the largest ones, which are called "hypermarket" address all the segments of the population. These stores providing all the necessities of people have become one of the most popular places for purchasing in our country. Besides that, these stores take a significant portion of the annual return in the sector. In short, it can be stated that these stores are the driving force of food retailing (Karahan, 2014, p. 1).

There are many interest groups making use of the information of these businesses, which are called the driving force. Some of them are the state, employees, suppliers, clients, and credit companies. Besides the factors such as investors' capacity to invest, and sectoral status, competition environment, and relationships (with individuals and institutions) of business, also the financial information is very important in order for creditors to determine an accurate credit policy. For these reasons, the financial status analyses revealing the financial position of businesses has become a must in order for business interest groups to be able to make accurate decisions.

From this aspect, the present study aims to determine the financial performances of three store chains (BIM, MIGROS, CARREFOURSA) traded in BIST by using ratio analysis, which is one of the financial analysis methods, and to compare the financial performances of store chains by seasons. In BIST-Retail Trade Sector, there are 12 retailers. Among these companies, BIM, MIGROS, and CARREFOURSA operate as store chains in this sector. In the present study, the financial statements of years between 2015 and 2018, which have been declared in BIST, publicized by these companies, and subjected to independent auditing, were used. Among 12 companies traded in the food industry in BIST, the financial statements of 3 companies, periodic data of which can be regularly obtained, were used. In analyses, the financial statements of selected companies were subjected to liquidity, operation, financial structure, and profitability rate analyses.

As a result of the analyses, the results summarized below were obtained:

When comparing the companies, the order of companies by current ratio and liquidity ratio was found to be as follows: MİGROS, BİM MAĞAZALARI, and CARREFOURSA. Besides that, the cash ratios of BIM and CARREFOURSA companies were observed to be close to the general standard. When examined together, these three ratios suggest that these three companies are risky in terms of paying their short-term debts, although their cast ratios were found to be sufficient.

The accounts receivables return rate of MIGROS was found to be higher than those of other companies. The stock turnover rate of BİM company was higher than others and BİM has invested less fund in stocks. Considering the asset turnover rate, BIM was found to be above the general average, 
whereas MIGROS and CARREFOURSA were below the average. It can be stated that the working capital of MIGROS, which was insufficient in the first 2 years, was sufficient for paying the short-term debts but still below the general standard. The order of working capital was found to be as follows: BIM, MIGROS, and CARREFOURSA. Using the working capital level, it can be stated that the companies have a sufficient level of sales. It was determined that the company using its tangible assets most efficiently was BIM, which had the rate above or at the level of the general standard.

Considering the financial structures of companies, it can be stated that the company having the values closest to the general standards was BİM. Although below the general standard, a balance between liabilities and equity capital constituting the financial structure was observed. The company with the best term structure of short-term debts was MIGROS. From the aspect of meeting the short-term debts, the weakest company was found to be CARREFOURSA. It was determined that, when compared to the other companies, MIGROS had a lower level of short-term debt but still higher than the normal level. From the aspect of long-term debts, the values obtained were also higher than the normal levels. Examining both ratios together, the debt ratio of the company was high and the equity capital ratio was low. Considering the general standards, it can be stated that the financial structure of the company is risky for current shareholders, potential shareholders, and credit companies.

The short-term liability ratio of BİM was above the normal limit but its long-term debt rate was much lower than the normal value. When compared to the general standards, the short-term debts of CARREFOURSA were much higher and long-term debts were much lower. However, since the company's equity capital ratio is much lower than the general standards, it is thought that the financial structure of the company is risky. It was determined that the fixed asset/equity capital rates of MIGROS and CARREFOURSA were much higher than the desired level.

MIGROS's markup value, which constitutes the normal area of activity, is higher than the other companies. From the aspect of operating profitability, the company at the best position was found to be BIM store chain. From the aspect of the net profit ratio, the most negative values were those of CARREFOURSA and MIGROS. MIGROS (except for the year 2017) and CARREFOURSA made losses between 2015 and 2018 and it negatively affected their return on equity. The company with the highest return on assets was found to be BIM Grocery Store Chain. The company having the lowest return on assets was found to be CARREFOURSA.

In the food market, it is generally believed that the customers with middle and high-income level prefer MIGROS and CARREFOURSA stores whereas the middle and low-income customers prefer BİM, and that the prices in BIM are more affordable when compared to MIGROS and CARREFOURSA.

However, in the present study, it was determined for the food retailing sector that the contribution of middle and high-level customers to the company's profitability and efficacy was low but that of middle and low-income customers was found to be high. One of the reasons for this finding is that the customers can easily access BİM stores since there are plenty of branches throughout the country. Moreover, BİM has a higher level of sales because the prices offered in BIM stores are considered more affordable by the customers. Thus, it can be predicted that the policy of "low profit-high sales" had a positive contribution to the company's profitability and efficacy. 